\title{
Om Hölderlin
}

\section{Jeppe Brixvold}

Det er en ofte anvendt floskel at digteres biografi ikke kan adskilles fra deres værk. I tilfældet Hölderlin, født i 1770 og død i 1843, bør dette dog ikke blot forståes i overført betydning, idet hans livsbane på næsten skematisk vis formulerer en bevægelse som også findes i hans digte. Der er for eksempel en sær konsekvens $\mathrm{i}$, at den kan deles præcis på midten, da Hölderlin er 36 1/2 og gennemlever det første deciderede udbrud af sindsyge. Det er i september 1806, hvor vennen Isaac von Sinclaire endelig opgiver ham og sender ham på klinik. Sinclair har igennem et par år forsøgt at få Hölderlin bragt tilbage til verden gennem en fiktiv stilling som hofbibliotekar i Homburg til en løn som Sinclair selv i skjul betaler, man da Hölderlins raserianfald og depressioner i løbet af 1806 bliver stadig hyppigere, er konsekvensen uundgåelig, og han flyttes mod sin vilje til Tübingen, hvor han skal komme til at blive til han dør.

Det første års klinikophold og forflytningrn i 1807 til tømmer Zimmers varetægt, markerer en definitiv afsked med den første halvdel af Hölderlins liv. Han bliver i det tårn hvor Zimmer 
installerer ham og han kommer ikke til at gense de steder han har kendt, og i hans mentale uligevægt forvrænges hans erindringer om fortiden $i$ en sådan grad at de reelt ikke længere eksisterer.

Hölderlins liv indtil da har mere være kendetegnet ved indre spændinger end ved ydre dramatik. Han er opvokset i Nürtingen, Württemberg i en pietistisk-lutheransk familie, hvis indadvendte og intense gudsdyrkelse har givet flere forskere stof til bearbejdelse af den dybe seriøsitet der præger hans poesi. I årene 177688 undervises han $i$ forskellige skoler og kostskoler i Nüringen og omegn, indtil han i 1788 starter på det lutheranske stift i Tübingen. Det er her, han efter nogle semestre bliver en del af det mest berømte studentermiljø i tysk litteratur, idet han kommer til at dele soveværelse med de jævnaldrende Hegel og Schelling. De tre læser Kant og Leibnitz og en vis Friedrich Jacobi, som gennem oversættelser af Spinoza har startet en stor diskussion om panteisme i Tyskland, og Hölderlin begynder at udvikle interesse for dels de panteiske tanker, dels den politiske idealisme som er kommet med den franske revolution. Han udgiver en række Schillerinspirerede digte og begynder arbejdet på romanen Hyperion, hvis vigtigste kerne skal være en politiske frihedskamp. Da han forlader stiftet i Tübingen i 1793, hjælper Schiller - som han kort forinden havde indledt et løst bekendt-skab til - ham til at arbejde som privatlærer. Imellem 1793 og 1802 arbejder han ialt fire steder som lærer, men beholder aldrig stillingerne i længere tid.

To møder i denne periode skal vise sig centrale for hele Hölderlins liv. Mens han midten af halvfemserne er i Jena, hvor han udbygger venskabet med Schiller, og begynder at arbejde på dennes tidskrift Die Horen, møder han den 19-årige jurastuderende Sinclair, som bliver en vigtig hjælp i de stadige kriser efter 1802. Tilsyneladende uden grund forlader Hölderlin imidlertid kort efter Jena til Schillers store skuffelse. Vigtigere endnu er dog mødet med Susette Gontard, den unge kone i familien hvor han får sit andet privatlærejob i starten af 1796. Hölderlin møder Susette på et tidspunkt, hvor han kæmper med intellektuelle problemer. Hans idealistiske teorier er under stadigt pres fra 
læsninger af Fichte og Kant, som insisterer på en afgørende forskel mellem mennesket og naturen, og han bekæmper et klassisk inspireret gudsbegreb, som ikke umiddelbart lader sig placerer $\mathrm{i}$ de nye tanker. Men Susette bliver nu en mulighed for at sætte tankerne i bero og fordybe sig i den ideale kærlighed han føler for hende. Efter alt at dømme er deres forhold meget lykkeligt i de tre år det varer før Herr Gontard begynder at synes, at hans kones forgudelse af den unge digter har udviklet sig til andet og mere end æstetisk begejstring. Hölderlin indføjer Susette som Hyperions smukke elskede Diotima i en revideret version af sin roman, men må i den virkelige verden forlade det Gontardske hjem i 1798. Han opretholder kontakten til Susette indtil 1800, men deres møder bliver efterhånden færre og deres breve mere opgivende.

Peioden mellem dette højdepunkt og det snarligt efterfølgende styrt er Hölderlins mest produktive. I 1799 er han igang med sine poetikalske fragmenter, de kryptiske Aufsätze, i 1800 fuldender han de store elegier Brod und Wein og Menons Klagen um Diotima, mens 1801 bringer hynmen Friedensfeier, elegien Heimkunft og en del glimmerende oder. En tolkning kunne væe at Hölderlin på dette tidspunkt er så fuld af sin verden, sine oplevelser, sine tanker og idealer at digtene nødvendigvis må komme frem. En mere dristig tolkning kunne hævde at han nu er så tæt på intet mere at være - på at blive et positivt intet som hans poetik siger det - at han er modtagelig over for det historiske, mytiske, retoriske og rytmiske stof som sproget vil lade ham forme. Under alle omstændigheder er det evident at hans liv derefter konsekvent bevæger sig mod en fjernelse af ham selv, at det bevæger sig mod den anden halvdel af hans liv, hvor det ikke længere er ham der styrer hvad der sker.

Efter i 1802 at være blevet adsat i sit sidste arbejsde som privatlærer, i Bordeaux, begynder Hölderlin en lang vandring alene over det franske centralmassiv. Han vandrer i tre måneder før han er i Stuttgard og da han når frem synes hans vanvid tydeligt. Han skriver senere, at han nu kan sige, som man siger om helte, at Apollon har ramt ham. Denne gang opnår han dog at falde lidt 
til ro igen. Sinclair inviterer ham med til en fredskonference $i$ Regensburg og arrangerer en udgivelse af hans seneste digte, blandt andet hymnerne Patmos og Andenken. Samtidig skriver Hölderlin i løbet af 1803 på oversættelser af Sofokles' Antigone og Kong Ødipus, arbejde som han høster en vis respekt for. Han bor hjemme i Nürtigen indtil Sinclair arrangerer det fiktive arbejde ved hofbiblioteket $\mathrm{i}$ Homburg for ham for at gengive ham hans værdighed. Sinclair er i starten skeptisk overfor Hölderlins usammenhængende tanke og tale, som han havlt mistænker for at være et spil på eccentricitet. Da Hölderlins tilstand imidlertid efter det første år forværres, og han helt bryder sammen da Sinclair, radikalen, på et tidspunkt anklages for forræderi mod prinsen af Würtemberg, er sygdommen tydelig.

I tårnet i Tübingen glider Hölderlin over i fuldkomment kaos med hensyn til sin egen fortid. Først er hans ræsonementer kun usammenhængende, han associerer frit mellem Hyprion, Ødipus og sig selv, og hans panteisme giver sig udslag i rodede teser om solens og månens øjne, men efterhånden bliver hans erindringer til schizofrene vrangforestillinger. Da den ungen digter Waiblinger, som er den første der skriver Hölderlins biografi, begynder at udspørge ham om Susette, svarer han: $\AA$, min Diotima... tal ikke til mig om min Diotima. Tretten sønner bar hun mig, den ene er pave, en anden er sultan, en tredje er kejser $i$ Rusland... Han begynder at omtale sig selv med pseudonymer, Scardinelli, Killalusimeno eller Buonoratti, og tiltaler gæster som Deres Højhed eller Deres Nåde. Livet er helt gledet væk for ham, i hvert fald et aktivt liv, og $\mathrm{i}$ stedet er der kun aktiviteten tilbage: digtskrivningen. Hvis folk beder ham om et digt, skriver han eet, et metrisk fuldendt digt, som blot er fuldkommen uden betydning. Det er et digt der ikke har anden betydning end at være et digt. Et digt som er en genlyd af digtningens egen stemme som Hölderlin kun kan referere og ikke påvirke.

Der er naturligvis ingen grund til at glorificere Hölderlins vanvid eller lede efter en genialitet $i$ galskaben. Det er ikke i tårnet i Tübingen han er interessant som digter, men før. Det bemærkelsesværdige er blot, at Hölderlin i hele sin bevægelse mod 
tårnet, $\mathrm{i}$ hele livsforløbet, på det nærmeste selv får angivet den hele bevægelse ind i myten, digtningens og sprogets kraft over digteren som så mange Hölderlinlæsninger har kredset om og stadig gør. At hans eget liv viser det sammenbrud og den drivenvæk-fra-sig-selv som man kan fremlæse i digtene. På den måde er det, at han selv bliver til en moderne myte. 


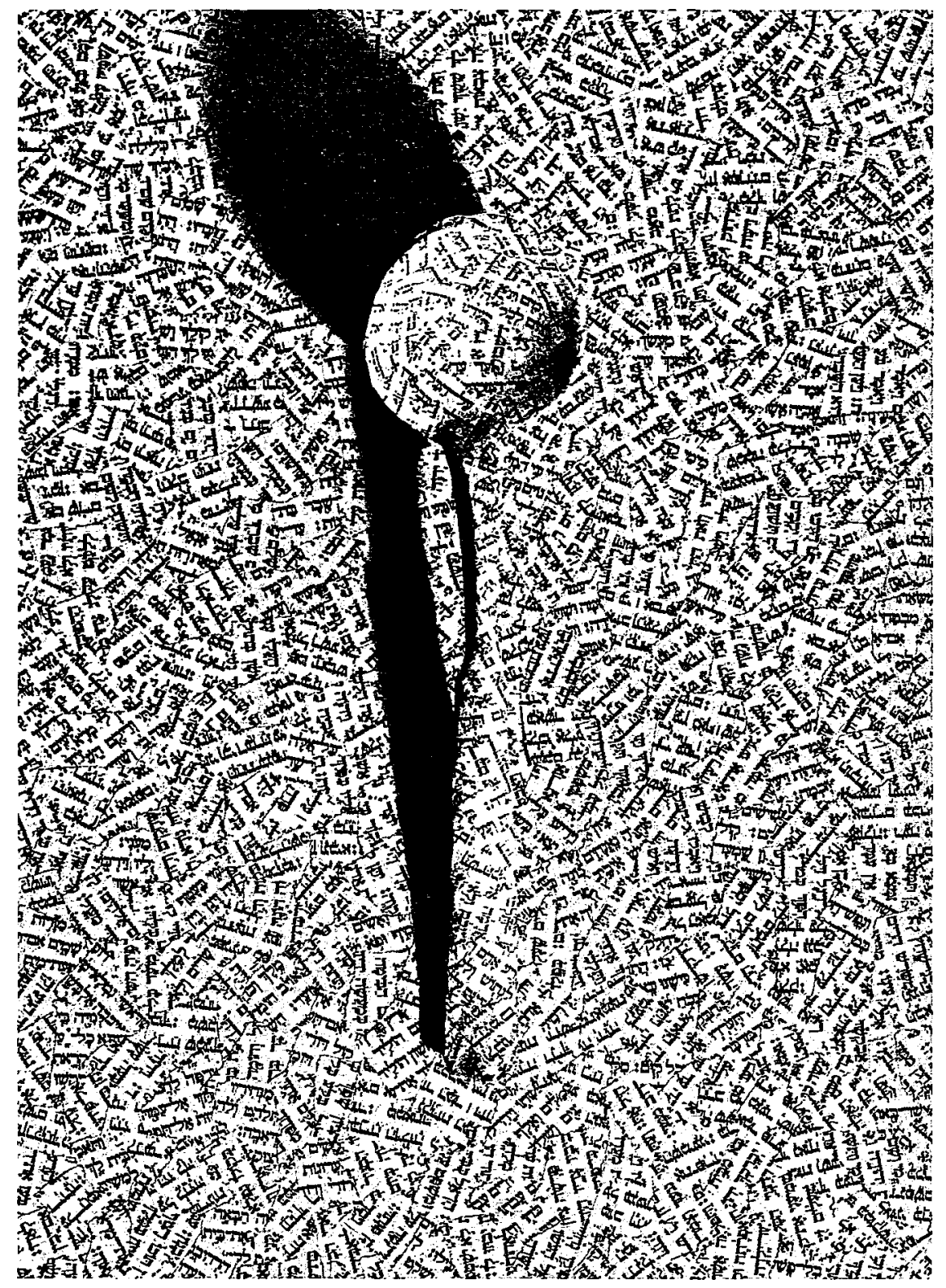

